\title{
IX I X WARSZAWSKI PIKNIK ARCHIWALNY Warszawa, 9-10 VI 2018 r. i 8 VI 2019 r.
}

$\mathbb{A}$ Warszawski Piknik Archiwalny pod hasłem Archiwa w ogrodzie przefrunął wraz z ptakami i motylami w Ogrodzie Botanicznym PAN w Powsinie w drugi weekend czerwca 2018 r. W tym roku odbywał się w plenerze podczas dwóch dni, w części czterdziestohektarowego terenu stworzonego ponad czterdzieści lat temu przez naukowców i botaników do celów nie tylko naukowo -badawczych, ale również rekreacyjno-edukacyjnych dla mieszkańców stolicy i okolic. Było to wymarzone miejsce na piknik, z dala od Warszawy i zgiełku. Co prawda z nie najlepszą komunikacją miejską, ale za to z dobrze prosperującą kawiarnią ze smakołykami i przepiękną parkową roślinnością, która wynagradza wszystko. Przebywanie w takiej scenerii jest w pełni satysfakcjonujące, gdy jest oczywiście pogoda, która w tym roku specjalnie na piknik była zamówiona przez obie Dyrekcje głównych organizatorów, tj. PAN Archiwum w Warszawie i PAN Ogrodu Botanicznego - CZRB w Powsinie. Ponadto, również z sympatii dla naszych działań pogoda wyjątkowo obdarzyła nas pięknymi, słonecznymi dniami z temperaturą, którą zapewne czerpała z gorącej, radosnej atmosfery wytworzonej przez samych archiwistów już w czasie przygotowań.

Pierwszy dzień Pikniku Archiwalnego od rana odbywał się równolegle w dwóch lokalizacjach, tj. w Pałacu Belwederskim i w Ogrodzie Botanicznym w Powsinie. W Belwederze, z inicjatywy Archiwum Prezydenta RP, które od wielu lat współorganizuje piknik, udostępniono do bezpłatnego zwiedzania 
wnętrza Pałacu, po których oprowadzali tamtejsi przewodnicy. Spod Belwederu zwiedzający mogli dostać się bezpośrednio do Powsina na dalszy ciąg pikniku uruchomionym na tę okazję zabytkowym autobusem, kursującym kilkakrotnie w ciągu dnia w dwie strony.

W Powsinie na terenie Ogrodu po gromkim, uroczystym rozpoczęciu pikniku w Villi Botanica (tzw. Fangorówce) przy dźwiękach zespołu dixielendowego oraz po przemówieniach głównych organizatorów i patronów można było uczestniczyć w wielu atrakcjach programu, gdzie każdy mógł znaleźć coś dla siebie.

Jak zawsze na przybyłych czekały ciekawe tematycznie i wizualnie wystawy, wykłady z prezentacjami i materiały filmowe (m.in. z Filmoteki Narodowej Instytutu Audiowizualnego). Wystawy nawiązywały często tematyką do znanych ogrodów (np. Zamku Królewskiego, Pałacu Prezydenckiego czy Ogrodu w Łazienkach Królewskich), a także przedstawiały sylwetki znanych botaników lub naukowców zasłużonych dla polskiej przyrody. Spotkania z zaproszonymi gośćmi specjalnymi: Dorotą Sumińską, (znanym lekarzem weterynarii, publicystką, obrończynią praw zwierząt), Małgorzatą K. Piekarską (znaną dziennikarką, publicystką i pisarką) i Andrzejem Kruszewiczem (podróżnikiem, ornitologiem, dyrektorem warszawskiego zoo) cieszyły się dużym powodzeniem, bo przybliżały ludzi z ogromną charyzmą zawodową, pasją i powołaniem do realizacji swoich szlachetnych celów - co można było zauważyć w ich bezpośrednim i serdecznym kontakcie z publicznością.

Współorganizatorami IX edycji Pikniku Archiwalnego było 20 instytucji (archiwów, muzeów, bibliotek) - najbardziej prestiżowych ośrodków administracji państwowej, naukowej i oświatowej. Patronat honorowy nad imprezą objął Prezes PAN, Naczelna Dyrekcja Archiwów Państwowych oraz Łazienki Królewskie-Muzeum, patronat medialny: Polskie Radio RDC, TVP Historia, TVP Kultura, TVP Polonia i TVP 3 Warszawa, a patronat logistyczny ZTM (dzięki uprzejmości którego był szybszy dojazd ze stolicy do Powsina).

Nastrój ożywiały i ubarwiały występy popularnych zespołów The Warsaw Dixielanders i Imprevisti, a także występy muzyczne utalentowanej młodzieży z LXIII Liceum Ogólnokształcącego im. L. Kossutha w Warszawie.

Intensywne spotkanie piknikowe trwało aż do późnego popołudnia, do godziny 18.00 .

W niedzielę, w drugi dzień pikniku, było nieco spokojniej, z nastawieniem na amatorów weekendowych spacerów, którzy mogli jeszcze skorzystać z okazji i obejrzeć wszystkie piknikowe wystawy, a także zapoznać się z materiałami filmowymi uczestniczących instytucji. Podczas dwudniowego spotkania było wakacyjnie i rodzinie, ale merytorycznie, co wzbudzało w uczestnikach cie- 
kawość i zainteresowanie. Po raz kolejny udało się udowodnić społeczeństwu, że Archiwa są nie tylko po to, aby je zauważyć i docenić w różnych życiowych sytuacjach, ale także można się z nimi zaprzyjaźnić i polubić z wzajemnością.

Jubileusz dziesięciolecia Warszawskiego Pikniku Archiwalnego obchodzono 8 VI 2019 r., tradycyjnie we wnętrzach i otoczeniu Pałacu Staszica. Było dużo wzruszeń, oficjalnych przemówień, kwiatów, wręczania pamiątkowych medali i wspomnień. Oprócz zaproszonych gości z władz Polskiej Akademii Nauk, Urzędu Miasta st. Warszawy oraz dyrektorów instytucji współorganizujących, w imprezie uczestniczyli przedstawiciele Archiwum PAN i PAU z Krakowa i z Wydziału Nauk Historycznych Uniwersytetu Mikołaja Kopernika w Toruniu. Podczas jubileuszu można było wysłuchać koncertu klawesynowego i obejrzeć tańce dworskie, przenosząc się w inną epokę historyczną.

W organizacji jubileuszowej edycji wzięły udział 23 instytucje, z których ponad połowa jest obecna na Pikniku od samego początku. Patronatu udzielili w tym roku: Prezes PAN, prof. Jerzy Duszyński, Prezydent m.st. Warszawy Rafał Trzaskowski, Naczelny Dyrektor Archiwów Państwowych dr Paweł Pietrzyk, a spośród mediów Polskie Radio S.A, TVP Historia, TVP Polonia, miesięczniki „Mówią Wieki” i „Skarpa Warszawska”, a także kanał o tematyce historycznej na You Tube Oblicza XX wieku.

Tegorocznym tematem były tajemnice archiwów, a więc to, co jest schowane, niedostępne, niewyjaśnione, ale drogocenne i bardzo intrygujące. Z okazji jubileuszu stworzono wspólną wystawę eksponowaną w Sali Lustrzanej, gdzie każda z współorganizujących instytucji mogła przedstawić na jednej z tablic najciekawsze materiały ze swojego zasobu (zdjęcia, dokumenty archiwalne, plakaty). Oczywiście, starym zwyczajem w wielu innych salach była okazja obejrzenia wystaw archiwalnych, które imponowały tematyką i bogactwem zarówno na planszach, jak i w gablotach.

Po raz pierwszy zaproszono publiczność Pikniku do zwiedzania podziemi Pałacu Staszica wraz z przewodnikiem. Podczas wycieczki, oprócz wysłuchania sensacyjnych informacji historycznych, można było zapoznać się z wykopaliskami z dziedzińca Pałacu Staszica oraz dokumentami i medalami Towarzystwa Naukowego Warszawskiego. Zainteresowanie tym tematem przerosło wyobrażenie organizatorów, bo okazało się, że zaplanowane cztery grupy zwiedzających nie były w stanie przyjąć wszystkich chętnych.

W tym roku nie było spotkania z gościem specjalnym na rzecz dwóch bardzo interesujących wykładów: o archeologii doświadczalnej - dynamicznie rozwijającej się dziedzinie, wspierającej poczynania naukowe i popularyzatorskie, a także o śladach krwi w Pałacu Staszica, czyli o świadectwie powstańczych walk. 
Oba cieszyły się dużym zainteresowaniem publiczności, a temu związanemu z Pałacem Staszica dodatkowo towarzyszyły wzruszenia, ponieważ okazało się, że na sali znajdował się naoczny świadek tych wydarzeń.

Wydarzeniom towarzyszyła oprawa muzyczna - można było posłuchać wspaniałego chóru Imprevisti oraz koncertu wirtuoza gitary, a na zewnątrz budynku od wielu lat towarzyszącego Piknikowi zespołu The Warsaw Dixielanders oraz energetycznego zespołu Rocking Therapy, który zdobył duże uznanie.

Na dziedzińcu również czekały atrakcje w postaci kolekcji minerałów z Muzeum Ziemi PAN, prasy drukarskiej z Muzeum Drukarstwa, a także gry planszowej i monidła na stoisku Narodowego Archiwum Cyfrowego. Chętni uczestnicy Pikniku mogli dokonać zakupów na stoiskach oferujących soki i przetwory naturalne, a także biżuterię i ceramikę. Zgodnie z programem zakończenie Pikniku nastąpiło o godz. 17.00 spotkaniem wszystkich organizatorów w Sali Lustrzanej, gdzie w ramach podsumowania i radości z wzajemnego świętowania czekała na wszystkich degustacja okazałego tortu z napisem: „Wiwant archiwiści! Wiwant wspólnych 10 lat!" 